\title{
Reception of literary works in the original and translation. A case study: Students' responses
}

\author{
Alla Perminova $^{1}$ \\ Independent Researcher, Barcelona, Spain
}

\begin{abstract}
The present case study applies the Reception Model of Literary Translation that places a high value on multiplicity and subjectivity of a target readership's response to a source text. The article highlights a threestage experiment that analyzes Literary Translation majors' responses to Yuriy Vynnychuk's novel Tango of Death in the original and in Michael M. Naydan and Olha Tytarenko's translation. The data on the students' response was collected by means of brainstorming sessions, in-class discussions, written reports, essays, and questionnaires. The informants agreed that on a large scale the translators succeeded in recreating the fusion of tragedy and humor of Vynnychuk's writing. However, on a small scale, certain translation decisions initiated polemics. Thus, some students criticized the recurrent translators' decision to alter the author's syntax, which is one of Vynnychuk's stylistic idiosyncrasies. Whereas others would fully approve of this technique, stating that otherwise the text would be incomprehensible for an English reader. Another stumbling block was associated with culturally biased units. Some students criticized the literality of conveying a number of Ukrainian set expressions, others saw in it a manifestation of a foreignization strategy. The students' feedback prompted a conclusion about the experiment helping to build up the learners' confidence in their professional expertise, boost their self-esteem and empathy, as well as to prepare them for actual translating projects of their own.
\end{abstract}

\section{Introduction}

One recently conducted quantum physics experiment suggests that there isn't such a thing as a shared objective reality. It provides evidence to the fact that under the right conditions, two people can observe the same event, see two different things happen, and both be correct. The idea seems to be quite relevant to the current reception-oriented trend in translation theory that harkens to the principles of Reception Aesthetics (H.-R. Jauss, W. Iser) and justifies subjective diversity of the target readership's response to the source text, with the translator, according to U. Eco, being a model reader [1].

Modern Reception studies in Ukraine (O. Bodnar, M. Lanovyk, A. Nesterov, S. Pavlychko, O. Rykhlo, etc.) encompass a wide range of issues, such as determining the place of a translator's reception among other forms of intercultural interaction; the study of the role of socio-political filters in intercultural communication; tracking the dynamics of

\footnotetext{
${ }^{1}$ Corresponding author: alla.perminova777@gmail.com
} 
assimilation of the work of a particular author by the recipient literary polysystem; establishing the meta-genre potential of the source texts; finding out the reasons for the emergence of the new forms of intercultural resonance and rethinking existing models of reception; analysis of the cross-border influence of various reception models, etc. Despite the apparent interdisciplinarity of the works raising these issues, there is an asymmetry in their research priorities, among which literary ones seem to prevail. This observation justifies the need to enhance the translation aspect in the study of the process and result of intercultural reception of literary works.

In previous research [2] I have elaborated a Reception Model of poetry translation, which conceives of an individual translator's reception as a means for modeling the metaimage of the source text through the filter of a translator's creative individuality, recipient literary polysystem, and sociocultural milieu. The topicality of the research was proven by its consistency with the four pillars of modern Translation Studies: anthropocentrism, functionalism, holism, and interdisciplinarity as well as consonance with Postcolonial Studies, since the research was based on the Ukrainian and Russian translations of works of eminent representatives of the national literature of the United States, where freedom of speech is an axiom of creative expression and a socio-political tradition.

However, an apparent limitation of the Model proves that as such it does not take into account the response of the target readership. Therefore, I have decided to improve on this constraint by studying emotional and intellectual responses of graduate students (Literary Translation majors) to a number of literary works both in the original and in translation.

\section{Methodology}

The main objective of this paper is to discuss an experiment in the course of which students' responses to Yuriy Vynnychuk's novel Tango of Death in the original and in Michael M. Naydan and Olha Tytarenko's translation were analyzed. The informants were 12 graduate students in my Literary Translation Workshop. The course is an integral part of the educational and research program for training MA graduates specializing in Philology 035.04 (Germanic languages and literatures [translation included]) at the Department of the Theory and Practice of Translation from English of Taras Shevchenko National University of Kyiv. The class met once per week during the spring semester of the $2018-2019$ academic year. The experiment was divided into three stages, with the first one lasting 8 weeks, the second - 4 weeks, and the third -3 weeks.

Since the key method applied in the framework of the Reception Model of literary translation is a stereoscopic analysis that needs to be conducted in reverse direction (as opposed to a traditional approach) - from target text(s) to the source text, the first stage of the experiment was dedicated to eliciting students' responses to M. Naydan and O. Tytarenko's translation without reference to Yu. Vynnychuk's original. That suggested involving students in linguo-cultural analysis of the translated text as well as incorporating the method of perlocutionary forecasting that consisted in an attempt to predict the potential English-speaking readers' reception, based on a set of background knowledge characterizing the recipient socio-cultural context. The data on the students' response to the translation was collected by means of brainstorming sessions, in-class discussions, written reports, essays, and questionnaires. The latter contained a number of open (attitudinal) questions as to the artistic value of the translation and its potential to become an integral part of the recipient's literary polysystem. The respondents were also asked to articulate whether the translation read as if it had been originally written in English; if so, whether it was possible to trace some affinity with American or other foreign writers enjoying international fame. In case the target text read as a translation the respondents were encouraged to specify the types of otherness (instances of lexical, grammatical, stylistic, or 
cultural interference) and to comment on their appropriateness. At the end of the first stage of the experiment the students were asked to write an essay on the cumulative image of Ukraine and Ukrainians with their values, beliefs, concerns, and aspirations as well as the meta-image of $\mathrm{Yu}$. Vynnychuk as inferred in the process of reading his novel in English translation. During the first stage of the experiment, I also engaged students in backtranslation of some parts of the English version of Vynnychuk's novel into Ukrainian to be further compared with the original at the second stage of the experiment. That necessitated the implementation of a variational approach [3] that suggested comparing a number of translation options correlating with the target audience's horizon of expectations. The conceptual core of the approach is the notion of variation as a complex of all possible interpretations of the source's meaning-and-sense unities, which were deduced using the method of deconstruction.

The second stage of the experiment was dedicated to reading and discussing Vynnychuk's novel in the original and technically reiterated the methodological procedure of the first stage. At that point the students had the opportunity to carry out a stereoscopic analysis of their back-translated passages with the Ukrainian original and M. Naydan and O. Tytarenko's translation, paying due attention to possible causes along with the nature and results of discrepancies with respect to the potential readership's response.

The third stage of the experiment was dedicated to a comparison of Naydan and Tytarenko's translation of Tango of Death and Vynnychuk's original in terms of the texts themselves (lexical, syntactic, stylistic features) as well as the students' responses to them. The contrastive study of the target and source texts (incorporating discourse analysis and structural methods of research: componential, distributional and transformational analyses) allowed the students to identify the zones of full, partial, and zero coincidence of the compared texts; to delineate the ways of restructuring of the source's meaning-and-sense unities and establish regularities with respect to the Reception Model of Translation. The respondents were also asked to compare their emotional and intellectual responses to both texts as reflected in their reports and questionaries submitted at two previous stages and to discuss their observations in a final essay.

The qualitative and quantitative parameters of the collected data on the students' response was further analyzed from two perspectives - that of the Reception Model of Translation and methodology of translators training.

\section{Research results}

The first stage of the experiment was designed to serve as a benchmark against which the students' response to Vynnychuk's novel Tango of Death would further be measured. Therefore, in the beginning with the translators' permission I gave my students the first one hundred pages of the English translation (which at that that time was only being prepared for publication) without either telling them that it was a translation or disclosing any information about the title and the author. Hence, the informants were exposed to a sample of anonymous writing claiming to be an original, or a "pseudo-original," of which, presumably, they did not know. In case some of them would be able to identify the novel, I asked them to hold back that information until they were asked to share it with others. However, the next time the class met the students had absolutely no doubts as to the text being a translation from Ukrainian for a number of reasons. The main argument was that only a native Ukrainian with a profound and extensive knowledge of the history of Ukraine, its customs, traditions, as well as the nature of the Ukrainian people and their mentality could have authored such a text. That observation raised a very controversial issue frequently discussed among critics of literary translation - is it good or bad for a translation not to pass for an original? Therefore, I encouraged the students to express their position on 
that matter. Interestingly, the opinions were equally split. Half of the class responded that as target audience they would feel more comfortable with translators resorting to a domesticating strategy, when, in Schleiermacher's terms, they would move the author to the reader and achieve dynamic equivalence, which is adhered to by many translation scholars backing the ideas of Eugene Nida. The other half of the students expressed an opposing opinion as to the personal and social duty of a translator to serve the author and his/her work, to move the reader to the source culture and to foreignize, this way creating challenges conducive to the emotional and intellectual enrichment of the target readership with "otherness", which is not always susceptible to familiar notions and terms. According to the proponents of the foreignizing approach it is not only acceptable for a translation not to pass for an original, but rather necessary as an expected act of interpersonal and intercultural courtesy.

I believe that a teacher/instructor/mentor should not impose his/her views on his/her students and let them either come to an agreement or agree to disagree. That was the case with respect to our experiment, although personally I did share the position of the second group, which also happened to be in line with the ideas expressed by Venuti and Norn, who argue that any translation contains an act of violence against the original which could be either of a corrupt or abusive nature. Corrupt practices conceal their repeated acts of violence whereas the abusive ones bring the fact of translation from obscurity [4]. This very moderate abuse as a core principle of the strategy of foreignization allowed Naydan and Tytarenko to bring the Ukrainian national identity condensed in Vynnychuk's writing out of obscurity.

At the initial stage of the experiment the students were asked to describe the meta-image of the author as could be inferred from the text. Surprisingly, in the course of brainstorming the students came up with a list of characteristics that perfectly fit Vynnychuk - "a contemporary Ukrainian prose writer," "born most probably in Western Ukraine," "with a philological background, a deep knowledge of Ukrainian history and culture," "an intellectual," "a gourmet and probably a perfect cook," and "100\% male, either a womanizer or someone who wants to pass for a womanizer." The last conclusion mostly stemmed from reading the intimate scenes incorporated into Vynnychuk's writing, which can be illustrated by the following fragments: "It had been two weeks since the attempt to end her life. The suicide greeted him with a joyful smile, as if nothing had happened, as if she were not a patient, but a nurse. Her smile was not even so much joyful as lustful. It seemed as if she were about to swallow him, sucked all over like a caramel candy." [5] "Від спроби покінчити з життям минуло два тижні, самогубиия зустріла його радісною усмішкою, мовби нічого й не трапилося, мовби вона тут не пацієнтка, а медсестра, усмішка ї̈ була навіть не так радісна, як ласа, здавалося, вона ось-ось його проковтне, наче обсмоктану карамельку." [6]; “And the fourth person without underwear was Leah /.../ We found that out from Yosko, but I myself once ascertained it when we played hide and seek. Leah was eleven then, and I was fourteen. Her eyes were like two embers, and her luscious cherry lips looked as if she had just drunk a quart of blood, and there in the really thick elderberry bushes, where she and I had hidden, Leah sat on the grass, bending her knees in front of her and grabbing them with her hands, and I laid down on my back. Both of us were hiding and didn't say a word." [5] “...четвертою особою без майтків була Лія /.../ Про ие ми знали від Йоська, але я й сам колись у иьому переконався, коли ми бавилися у хованки, Лії було тодi одинадиять років, а мені чотирнадиять, очі у неї були, як дві жарини, а повні вишневі вуста виглядали так, мовби вона щойно випила кварту крові, $i$ от $y$ густелезних кущах бузини, де ми з нею заховалися, Лія сіла на траву, зігнувши перед себе коліна й обхопивши їх руками, а я ліг долілиць, обоє ми причайлися $i$ не розмовляли..." [6]. 
The students were practically unanimous in their response to these scenes. The majority were convinced that the book would be better without them. Their elicited emotions ranged from mild embarrassment to even repulsion, the evidence for which is provided by the following excerpts from the informants' final essays: “... Reading the passages with erotic scenes in them aroused the feeling of mild aversion to the events depicted, both for the choice of the setting and the wording - and you should take my opinion with a grain of salt as I am a committed feminist. I can see how a less gender-equality conscious reader might find these scenes funny; they were not in my case and, honestly, these scenes took a great deal of patience from my perspective"; "the entire kind of erotic situation is enough to make any reader feel at least slightly uneasy with the amount of detail paid to describing the maidenhood of an eleven-year-old girl, even though it was related from the perspective of a teenage boy".

However, when later on during the second stage of the experiment the students were asked to dwell on their response to the same scenes as presented in the original they reported feeling considerably less uneasy, primarily because they had already been prepared for that overtness but also as a result of the richness of the author's style, a spicy blend of special literary vocabulary (terminology), colloquialisms, and dialectal words, but primarily due to the author's choice of softer, more elevated equivalents for the parts of the female body, with the "body" itself being referred to as "cman," "breasts" as "nepca," and "lips" as "вycma." One of the respondents stated: "Sure enough such inter-register equivalents are available in the Ukrainian language and are probably missing in English, which makes the original a bit more erotic rather than blatantly realistic". Nevertheless, the students agreed that apparently such scenes comprise an integral aspect of the author's stylistic trademark - the fusion of tragedy and humor, which was adequately conveyed in translation, and that the author's intention was to make the scenes in question not just merely vulgar and cheap, but rather to turn them into something funny, casual, and a tiny bit ridiculous, taking into account their settings - a psychiatric hospital, the bushes, and the library to name just a few.

Another aspect of Vynnychuk's writing that caught the respondents' attention even while reading it in translation was its intertextuality, literary kinship with other eminent writers (Haruki Murakami's Hard-Boiled Wonderland and the End of the World, Dan Brown's The Da Vinci Code and The Lost Symbol, etc.), particularly in terms of their technique of intertwining seemingly separate storylines. Here is one of the respondent's feedback: "As an omnivorous reader, I have more than once come across a similarlystructured plot, built upon the merging of two seemingly separate storylines. The first book that comes to mind is Haruki Murakami's Hard-Boiled Wonderland and the End of the World, which initially appears to be extremely confusing but opens up toward the end; the author, however, starts giving out the hints somewhere closer to the middle of the story but an unsuspecting reader would not be able to grasp them."

From my perspective, with a particular interest in the idea of inter-literary attraction, I was not surprised when Vynnychuk revived in me my experience of reading The Shadow of the Wind - one of the best-selling novels of an outstanding Spanish writer Carlos Ruiz Zafon. Its meticulously crafted mosaic of a labyrinthine plot, a blend of historical fiction, occasional farce, existential mystery, and a passionate love story all resonate with the intricate narrative and stylistic motifs of Vynnychuk's Tango. To prove my point, I read one of the passages of Zafon's novel to the students - the description of the library - the cemetery of forgotten books: "This is a place of mystery, Daniel, a sanctuary. Every book, every volume you see here has a soul. The soul of the person who wrote it and of those who read it and dreamed with it. Every time a book changes hands, every time someone runs his or her eyes down its pages, its spirit grows and strengthens...In this place, books no longer remembered by anyone, books that are lost in time, live forever, waiting for the day when 
they will reach a new reader's hands...According to tradition, the first time someone visits the place, he must choose a book, whichever he wants and adopt it, making sure it will never disappear, that it will always stay alive” [7]. The students agreed that the passage might as well be seamlessly integrated into Vynnychuk's description of the library in Tango of Death.

Having read and discussed the translation without reference to the original, the class moved on to read and discuss the Ukrainian text. Something that was initially conceived as a "déjà vu" experience turned out to be a paradigm-shifting one. The first time the students met at the second stage of the experiment, they spoke of their frustrated expectations. Everyone had expected that reading the original written in their native language would place them back into their comfort zone, which never happened. At some points the original proved to be even less reader-friendly because of its complicated syntax, a whole range of culturally-biased as well as dialectal vocabulary. The initial response to frustrated expectations was quite controversial. Some students complained that in being unable to understand the meaning of quite a few words they began to question their own Ukrainian identity and felt somewhat inferior to the author and those readers who were able to fully appreciate his richness of style. A quote from one of the final essays explicitly indicates this: "The novel is oversaturated with culture-biased and dialectal words used for an accurate depiction of the atmosphere of Lviv at the time. Not being born into that particular subculture, I found it way too obtrusive and tiresome, which makes it not too hard to predict the reaction of non-Ukrainian readers to that sort of writing and the amount of effort they will have to exert to understand the text and derive emotional and intellectual pleasure...".

Others, on the other hand, were grateful for the linguistic challenge posed by the author and eagerly welcomed this learning experience, which was reflected in one of their reports: "Frankly speaking, Tango of Death was not an easy book to read. My knowledge of my native Ukrainian language turned out to be inadequate. Therefore, I no longer perceived the book with my mind, but rather with my heart. This is probably what tango dancers do they dance with their hearts". However, at the end of the second stage of the experiment all the students agreed that having read Vynnychuk's novel, they felt more Ukrainian than before and expressed a hope that the English translation would have the same effect for the English-speaking readership of Ukrainian origin. Below is an excerpt from an essay submitted by one of the respondents that on balance summarizes the overall group's response to the novel: "I was lucky enough to discover Tango of Death. It was awarded the BBC Ukrainian Book of the Year title in 2012, and the book absolutely deserves it. Initially it might seem too overwhelming and too tiring to read. Just think of the first 50 or so pages of extremely detailed description of western Ukrainian culture. And while cultural studies researchers could not be happier holding this encyclopedia - we, ordinary human beings, are nervously trying to recall how Nasturtiums look like. But there is a good reason for all those details. They add a unique flavor to the novel: it feels so Ukrainian, just like the finger-licking borsch your mother has just cooked for you".

At the end of the second stage of the experiment the students were asked to compare the passages they had back translated from the English version into Ukrainian with the corresponding passages of Vynnychuk's authentic writing, and define the zones of complete, partial and zero meaning and sense coincidence of the stereoscopically analyzed texts. According to the students' reports a mean of $88 \%$ of the compared texts fell into the zone of complete and partial coincidence, whereas the remaining $12 \%$ mostly accounted for a number of inter-register shifts, for instance (with respect to the above examples) "hospital" was back-translated as "лікарня," whereas in Ukrainian original the author uses "лічниия"; "picturesque surroundings" into "мальовниче довкілля / місиевість / місиина" (in the original “мальовничій околиці"); "underpants” into “спідня білизна”/ 
“трусики” (in the original - “майтки”). Similar kinds of discrepancies occurred while backtranslating a wide range of other stylistically neutralized English correspondences to expressive Ukrainian lexemes, some of which are presented in the following table:

Table 1. Variation of translators' decisions

\begin{tabular}{|l|l|l|}
\hline English translation & Students' back-translation & Ukrainian original \\
\hline in its last days & $\begin{array}{l}\text { залишилось недовго; доживає свій вік; } \\
\text { от-от завалиться }\end{array}$ & на ладан дихає \\
\hline repaired & відремонтував; полагодив & підрихтував \\
\hline fat toad & товста / гладка жаба & пульката ропуха \\
\hline frowning & насупивши брови; зморщити лоба & набурмосившись \\
\hline lavatory & туалет; вбиральня & кльозет \\
\hline water closet & туалет; вбиральня & кльозет \\
\hline balcony & балкон & балькон \\
\hline
\end{tabular}

These examples clearly demonstrate that the students tended to opt for literal equivalents to the English lexical units, which allowed them to predict that the effect of the scenes in which these units occur might be not as humorous to the English reader as it is on the reader of the Ukrainian original text, which is abundant in stylistic nuances. Sometimes even a single letter makes a difference to reception, just as in the case with "балькон" - a colloquial variation of a normative word used by the author along with other expressive means to imitate the actual speech of his characters. On the other hand, there were quite a few instances when by means of backtranslation the students arrived at exact coincidence with the original (e.g. "penetrating playing" - "прониклива гра" - "прониклива гра"), but they would rather translators had exercised more freedom in their choice of English correspondences ("heartfelt" instead of "penetrating").

The results of the stereoscopic analysis prompted the students' conclusion as to the inevitability of losses that happen in any translation, especially in the cases of the texts characterized by a high density of stylistically marked units. This activity also allowed the students to exercise variational approaches to translation and served as a bridge connecting the second stage of the experiment with the third.

As mentioned before, the third and final stage of research was dedicated to a comparison of the original and the translation, namely to the students' responses to both texts, and was marked with heated debate. All students agreed that the translators did a great job on a macro scale in recreating the fusion of tragedy and humor of Vynnychuk's writing. They emphasized full synchronization of their responses to the original and translation - they cried and laughed at exactly the same scenes, and both rides on the emotional rollercoasters of the translation and the original were equally breathtaking. Below is what one of the students wrote in her essay: "In my opinion, the charm of this book lies in a skillful mixture of humor and tragedy, which was adequately rendered in translation. Many episodes ironically evoke personal memories in readers' minds. When one reads something and feels that he/she can relate to - that is the key to readers' hearts. So, you have barely stopped laughing and in just a couple of paragraphs the author takes your heart out by describing the atrocities of war, revealing the evil blood-thirsty side of humans...And then, again when you still have not had a chance to wipe your tears the novel resurfaces deep philosophical topics and engages you into some serious thinking about the sense of life and the meaning of death."

Since "death" is one of the leitmotivs of the novel the students were asked to pick up various relevant passages in the original and translation and dwell on their response to them. One of the chosen passages is given below:

"I wonder if it's a man or a woman," mom asked some merchant woman standing nearby. 
"A girl," she replied and with a colorful scarf wiped the corner of her dry eye. "She's so young... They say over a tragic love."

"Come on! Such things still happen?"

"It happens, it happens. He made a baby with her; then he dashed off to the army."

"I'd show him the army!" Mom shook her head. "Oh, I'd give it to him! I'd go to the staff headquarters, to the Minister of War, all the way to Pilsudski, but I wouldn't allow it. Nope, no way. " [5]

- Цікаво, то чоловік чи жінка, - поцікавилася матінка в якоїсь перекупки, щео стояла поруч.

- Дівчина, - відповіла та і втерла рогом квітчастої хустини сухе око. - Така молода... Кажуть, через трагічне кохання.

- А йдіть! Ще й таке буває?

- Буває, буває. Зробив їй дитину, а сам чкурнув до війська.

— Я би му дала військо! - похитала головою матінка. — Ох, я би му дала! Я би поӥхала до штабу, до самого військового міністра, до Пілсудського б дійшла, але би так не попустила. Шо нє, то нє [6].

The student analyzing her response to the example above underlined that even though the scene refers to suicide, she could not help smiling while reading it in both versions. She pointed out that the translation produced the same effect on her and largely due to the translators' coming up with perfect English equivalents to stylistically marked source items this way making the text sound natural. ("Come on!" - "A üdimb!"; "Nope, no way" “Шо нє, то нє”).

At that stage of the experiment the informants were also asked to decide on the funniest passage of the novel, and the students almost unanimously agreed on that being the scene with a laxative prank, depicting how Mr. Katsenelenbogen (Mr.Teacher) was dancing away a "tumbalalaika" in front of the lavatory with all hilariously embarrassing consequences of the water-closet being occupied. The respondents expected this scene to be equally funny for both Ukrainian-speaking and English-speaking audiences, as the humor described in it is mostly situational, which poses hardly any difficulty for translators. However, only by stereoscopically analyzing the passage in translation with their backtranslations and the original the students were able to fully appreciate the brilliance of the translators' decisions (e.g. "When she found out what an unpleasantness had befallen him, she knocked on the door of the water closet, but also heard the moaning and unseemly fartissimo then she rushed back into the house and carried out a pot and told Mr. teacher to do his obligation in the pot” [5] - “коли ж довідалася, яка прикрість його спіткала, то постукала в двері кльозету, але почула теж самий тільки стогін $і$ непристойне perdissimo, тоді метнулася назад у хату і винесла горщика та сказала панові вчителеві справити потребу в горщик"[6].)

Nevertheless, on a smaller scale - some translators' decisions proved the subject of polemics. This brings us back to U. Eco's theory of textual cooperation that gives the reader a key role in the process of making sense. According to Eco, the text creates a Model Reader capable of actualizing the various meaning-contents in order to decode the possible worlds of the narrative. This reader fills in the many gaps in the text, which is never completely explicit. Hence, one and the same translation decision would be criticized by some readers and praised by others [1]. Thus, some students criticized the translators' recurrent decision to alter Vynnychuk's syntax, which is one of his stylistic idiosyncrasies. In their opinion, the apparent change of the flow caused by breaking longer sentences into a series of shorter ones changes the perception of the events by the readers, making the narration sound abrupt and choppy. Whereas others would fully approve of this technique, stating that otherwise the text would be incomprehensible for an English reader. (e.g.: "One such summer, when the heat was stifling, and a breeze hovered over the trees, Auntie Lucia, 
having exhausted herself by the stove, sat down in an armchair and dozed off, forgetting to turn off the gas under the pot with the hot preserves. The fire happily continued to lick the metal; the berries frothed, boiled, bubbled, and rose, and reaching the edges of the top of the pot, overflowed onto the stove and put out the fire, but the gas continued to flow and filled the kitchen with its sour smell. Aunt Lucia smiled in her sleep, stretched out her hands to meet someone, and whispered: "Finally ... you've come back...." [5] - “Одного такого літа, коли спека забивала подих $i$ повітря мріло понад деревами, тета Люиія, розморившись біля плити, сіла у фотель* $i$ задрімала, забувши вимкнути газ під мидницею і гарячими конфітурами, вогонь продовжував весело облизувати метал, ягоди шумували, булькали, пузирилися і піднімалися, а досягнувши країв миднииі, вибігли на плиту й загасили вогонь, але газ продовжував витікати $і$ наповнювати своїм кислим запахом кухню, тета Лючія усміхнулася крізь сон $i$, простягнувши руки комусь назустріч, прошепотіла: «Нарешті... ти повернувся...” [6].

Another stumbling block was the way of rendering culturally biased units. Some students criticized the literality of conveying a number of Ukrainian expressions (e.g. "At least if a duck kicked you!" - "аби тебе качка копнула!", "without a hundred grams you won't figure it out" - "без сто грам ніяк”, “грати на нервах" - "play on the nerves" etc.) others saw in it a manifestation of the global strategy employed by the translators foreignization, arguing that one may not Americanize a literary work which is so deeply rooted in the Ukrainian culture, just as one is not able to rewrite a culture. There was another opinion expressed in favor of a more balanced approach, since, according to one of the respondents "not in every case does foreignization prove to be the best option, and more natural English equivalents might have been a viable solution, that would have also made the text more reader-friendly."

Despite minor critical observations the respondents pointed out perlocutionary symmetry of the Ukrainian and English versions of Tango of Death, in this way underscoring the high quality of Naydan and Tytarenko's translation, appreciating their tremendous efforts to make Vynnychuk's work a part of the recipient literary polysystem.

\section{Discussion}

I have intentionally postponed expressing my views on the subject of the students' debate with respect to the in/appropriateness of certain translation decisions and their subsequent impact on the target readers' reception, because my opinion is consistent with the quantum physics experiment described in the introduction - any translator's decision may be viable and justifiable provided it does not stem from an inadvertent misinterpretation or deliberate distortion of the source text message. The choice of the material for the experiment - the novel Tango of Death was not accidental either. It was prompted by a belief that the demarcation line between "good" and "bad" in any kind of human endeavor is often blurred and twisted just like the moves in a tango. So that the students could internalize this idea I asked them to do research into the nature of the tango as a dance and with their acquired knowledge in mind to look at the novel under discussion and its translation from various perspectives. Hence, the students found out that tango is about feeling and sensitivity, it has no agreed upon formula, no designated rules, just collectively shared sequences that a leader can use interchangeably. It is an improvised dialogue, a negotiation between dancers, with no choreography, no predetermined pattern, just endless unpredictable new formations. One of the students mentioned that while reading about characteristics of the dance she realized how similar that explanation was to her experience of reading Vynnychuk's book with all its intricate "gyros" (turns) of the plot, themes, and registers. Another parallel arose with the art of embracing. While dancing the tango it is important to embrace the music and not your partner. This is what makes the tango a very intimate and 
a very social experience at the same time. The charm of the tango lies in the fact that with each person it acquires a different character and style. Thus, the students were able to discover the charm of Vynnychuk's Tango - with every reader it finds a different character and style, and obviously a different response. The same is true about its translation. Although the tango is conceived as a dance of equals, one of the two partners has to lead. Obviously, Vynnychuk is a perfect leader, using a whole range of the tricks of his literary talent to teach the reader how to wait for the author on her axis so that he could take her from it wherever he likes. One of the most important talents a leader must develop is the ability to make one's partner shine. This is what, according to the students' response, Yuriy Vynnychuk, Michael Naydan and Olha Tytarenko succeeded in doing - making their readers shine, having gone through the literary catharsis of laughter and tears of compassion.

It is not incidental either that the debate around similarities and discrepancies of the students' responses to Vynnychuk's Tango of Death in the original and in translation basically comes down to the long-standing pragmatic dilemma which has been an object of translation scholars' polemics at least since F. Schleiermacher, whose two methods of moving the reader to the author vs. moving the author to the reader were ultimately labelled by L. Venuti as "foreignization" and "domestication." In his seminal work, The Translator's Invisibility: A History of Translation [4], Venuti argues that the so-called domesticating practices in the course of translating cultures have contributed to the truncation or suppression of the linguistic and cultural otherness of source texts. Venuti sees a solution to this problem in the strategy of foreignization, which aims at sending the reader abroad in the sense of challenging dominant values in the receiving culture and stepping away from ethnocentric narcissism. In one of his recent books, Counter Instrumentalism [8], Venuti speaks about instrumentalism as a model of translation that has dominated thinking in translation theory, commentary and practice for millennia. It conceives of translation as the reproduction or transfer of an invariant that is contained in or caused by the source text. In author's opinion, this model is simplistic, and moralistic, which has resulted in the marginalization of translation by literary studies from the vantage point of which the best translations are ones that do not contaminate the integrity of the source text rather than the ones that bring the translator out of obscurity of her / his work. As such, instrumentalism, according to Venuti, must be replaced with translation research and practice that are radically hermeneutic. Hence, inspired by German romantic poets and critics, the author elaborates a hermeneutic model that conceives of translation as an interpretive act that on the one hand inevitably varies source-text form, meaning, and effect according to the intelligibilities and interests in the receiving culture, but on the other can encompass different concepts of equivalence. According to this model, a translator turns a source text into a translation by applying interpretants - formal and thematic factors that constitute the translator's decision-making process - which results in a relatively autonomous target text. This is what Michael Naydan and Olha Tytarenko seem to have accomplished in their translation of Vynnuchuk's novel Tango of Death.

The idea of relative autonomy of the target text as well as that of the hermeneutic approach resonates with the core principles of the Reception Model of Translation elaborated in my previous research [9]. From the standpoint of the Reception Model, translation is understood as a process and result of the translator's reception, which shapes the creation of the meta-image of the author of the original and linguistic culture he or she represents in the minds of target readers. The translator is the human locus of intercultural activity that leads to the creation of a target text as a rightful component of the recipient literary polysystem. Therefore, the translation is secondary with respect to the original only chronologically. The translator's reception of a literary work is an act of co-creation with the author, aimed at intellectual and aesthetic stimulation of the target reader, which, on the 
one hand, leads to the popularization of the work of a foreign author, its ideological, national and artistic specifics; while on the other hand, it contributes to the expansion of the repertoire of the expressive means of the recipient language, as well as reveals the receptive potential of the target literature.

As mentioned above, the key method of research applied in the framework of the Reception Model is that of stereoscopic analysis. This method proved its efficacy in the course of the experiment when the respondents were asked to perform backtranslation of a number of passages of the English translation, comparing them with the ultimate source the Ukrainian original, and determine the variability of the translators' decisions in restructuring the source meaning-and-sense unities, particularly in the passages characterized by the abundance of stylistically (and culturally) marked units, semantic and syntactic ambiguity, and high potential for multiple interpretations.

The experiment allowed the students to verify the fundamental principles of the Interpretive Theory of Translation (D. Seleskovitch, M. Lederer) according to which translation is a matter of sense emerging from the interaction of linguistic meaning and the interpreters' "cognitive complements" (language command, world knowledge, situation appraisal). In line with the interpretive approach, translation is not a linear operation of transcoding of the linguistic meanings of the source language into equivalent linguistic meanings of the target language, but rather a dynamic process of comprehension, deverbalization, and reformulation.

\section{Conclusions}

In the course of the experiment the informants were able to shift the focus from the traditional study of the author's intended meaning to its reformulation conditioned by idiosyncrasies of a translator's reception and to realize that translation itself is one of the most proactive forms of the reception of source works, which is regulated by the complex scheme of intercultural and interpersonal interaction. Focusing on the pragmatic dimension of a literary work, the respondents became convinced that it is the most difficult to account for in translation. Therefore, the proposed experiment deepened the students' understanding of translators' strategies for achieving "dynamic equivalence" [10], of "doing things with words" [11], as well as bridging the gap between two cultures.

The students' feedback also prompted a conclusion about the experiment in helping to build up the learners' confidence in their professional expertise, in boosting their selfesteem and empathy, as well as in preparing them for actual translating, which is a nonlinear process of coming up with ideas that did not preexist. By realizing the importance of their opinion no matter how different it is from that of others, the students felt empowered, particularly when they were able to advise the translators on the book cover (since at the time the experiment was conducted the English version of Tango of Death was only in the process of being prepared for publication).

It is common knowledge that the second half of the XXth century was marked by a move from teacher-centered explanatory instruction to interactive student-centered learning, whereas student empowerment has become one of the cornerstones of the new millennium. This suggests both the process and the result of endowing students with the authority to make decisions about their own education and that of their peers; to exercise their freedom as creative individuals, and ultimately - to find their own voice in the polyphony of a cooperative setting. This is what the experiment described in the article succeeded in doing.

An empowered student is the main shareholder of the global community's future. That is why in order to gain a competitive advantage in the market of professional training, institutions of higher education have to incorporate interesting and useful courses into their 
curriculum that would serve the learner's needs and prepare them for a successful entry into their career. Therefore, it is in the methodology of translation studies and translators' training that I see a vast untapped and rewarding potential for further research.

\section{References}

1. U. Eco, The Role of the Reader (Indiana University Press, Bloomington, 1994)

2. A. Perminova, Translator's Reception of Contemporary American Poetry (Dmytro Buraho's Publishing House, Kyiv, 2015)

3. L. Hewson, J. Martin, Redefining Translation. The Variational Approach (Routledge, London and New York, 1991)

4. L. Venuti, Contra Instrumentalism. A Translation Polemic (University of Nebraska Press, Lincoln, 2019)

5. Yu. Vynnychuk, Tango of Death tr. by M.M. Naydan, O. Tytarenko (Spuyten Duyvil Publishing, New York, 2019)

6. Yu. Vynnychuk, Tango of Death (Folio, Lviv, 2015)

7. C. L. Zafon, The Shadow of the Wind, tr. by L. Graves (Penguin books, USA, 2004)

8. L. Venuti, The Translator's Invisibility: A History of Translation (Routledge, London and New York, 2003)

9. A. Perminova, A Reception Model of Poetry Translation (Based on Translation of XX th century American Poetry): a dissertation (Kyiv, 2016)

10. E. Nida, Toward the Science of Translating: With Special References to Principles and Procedures Involved in Bible Translating (E. J. Brill, Leiden, 1964)

11. J. Austin, How to Do Things with Words (Oxford University Press, Oxford New York, 1982) 